Praca poglądowa/Review paper

\title{
Weryfikacja planu leczenia, zaawansowane metody obrazowania - perspektywy.Na podstawie prezentacji ustnych podczas konferencji ESTRO 37 w Barcelonie.
}

\author{
Treatment plan verification, advanced imaging methods - \\ perspectives. Based on oral presentations at the ESTRO 37 \\ conference in Barcelona.
}

\section{Emilia Bukowicz ${ }^{1}$}

${ }^{1}$ Zakład Radioterapii, Wielkopolskie Centrum Onkologii w Kaliszu, Polska

\section{Streszczenie}

Celem pracy jest przedstawienie najważniejszych aspektów metody wyboru planu leczenia w codziennej praktyce klinicznej oraz zaawansowanych metod obrazowania na podstawie doniesień z konferencji ESTRO 37 w Barcelonie.

\footnotetext{
Abstract Barcelona.

Stowa kluczowe: CBCT, IGRT, wybór planu leczenia

Keywords: CBCT, IGRT, plan selection treatment

Adres do korespondencji

Emilia Bukowicz

Wielkopolskie Centrum Onkologii Ośrodek Radioterapii w Kaliszu

emilia.bukowicz@wco.pl

e-mail: emilia.bukowicz@wco.pl
}

The aim of this paper is to underline the most important aspects of plan selection in daily clinical routine and perspectives of advanced imaging methods that were presented during ESTRO 37 conference in 


\section{Obrazowanie}

Jednym z wielu tematów pojawiających się podczas wystąpień na konferencji ESTRO 37 w Barcelonie było codzienne obrazowanie w kontekście weryfikacji planu leczenia. Skupiono się na przedstawieniu rozwoju obrazowania na przestrzeni lat oraz zalet jakie niesie ze sobą możliwość wykorzystania obrazowania za pomocą rezonansu magnetycznego i jego integracji z aparatem terapeutycznym.

Weryfikacja obrazowa jest integralną częścią radioterapii onkologicznej już od wielu dekad. Pierwsze niekomercyjne systemy obrazowania kilowoltowego $(\mathrm{kV})$ byłypołączone z jednostkami kobaltowymi w latach 50. i 6o. XX wieku.Początkowo jeżeli plan leczenia wymagał weryfikacji, pacjent trafiał najpierw na symulator. Podstawą techniki IGRT (ang. Image Guided Radiation Therapy) w ubiegłym wieku było obrazowanie portalowe, za pomocą wiązki megawoltowej (MV), początkowo przy użyciu filmu i kasety, ograniczone do wizualnej oceny (porównania) ze zdjęciami z symulacji. W latach 80. powstały elektroniczne systemy portalowe. Obecnie obrazy 2D są porównywane z cyfrowo zrekonstruowanymi zdjęciami rentgenowskimi DRR (ang. Digitally Reconstructed Radiographs).Obrazowanie MV umożliwiarównież wizualizację struktur miękkich, jednak dawniej weryfikacja była ograniczona do anatomii kostnej, pozostawiając ruch guza w stosunku do anatomii kości bez korekty, chyba, że wszczepione zostały odpowiednie markery. Obrazowanie $\mathrm{kV}$ zapewnia lepszą rozdzielczość i kontrast tkankowy niż obrazowanie MV, tym samym bardziej precyzyjną weryfikację ułożenia pacjenta oraz jego ewentualną korektę.

Wprowadzenie techniki IMRT (ang. Intensity Modulated Radiation Therapy) wymagało zwiększenia dokładności dostarczania leczenia. Wprowadzono do praktyki klinicznej systemy do trójwymiarowej rekonstrukcji obrazów zintegrowane z akceleratorami: CT - on rails (komputerowy tomograf wielorzędowy poruszający się na szynach w pomieszczeniu z akceleratorem), czy MVCT (tomografia komputerowa realizowana za pomocą wiązki megawoltowej). Pod koniec lat 90. został wprowadzony zintegrowany system CBCT (ang. Cone Beam Computed Tomography) zainstalowany prostopadle do wiązki terapeutycznej. kV CBCT to obrazowanie za pomocą kilowoltowej wiązki stożkowej pochodzącej z lampy rentgenowskiej, która jest częścią akceleratora.Takie obrazowanie 3D zapewnia większy kontrast tkankowy i mniejszą dawkę w porównaniu do obrazowania portalowego. Umożliwiło to radioterapeutom zmniejszenie marginesów w planowaniu leczenia oraz toksyczności leczenia. Jednak dostępność takiego obrazowania w codziennej praktyce ujawniła zmiany, zarówno pod względem ruchu narządów, artefaktów, anatomii guza, również w wyniku jego odpowiedzi na leczenie [1].

\section{Zaawansowane metody obrazowania}

Kolejnym dużym krokiem ku poprawie jakościleczenia było wprowadzenie do radioterapii obrazowania 4D, szczególnie dla narządów z ryzykiem przemieszczania się, związanego między innymi z oddychaniem (np. płuca czy wątroba). W wyniku klasycznego obrazowania 3D ruchomego guza otrzymujemy zamazany obraz. Obrazowanie 4D zapewnia przede wszystkim ostrzejszy obraz, umożliwia codzienną weryfikację pozycji przemieszczania oraz jej monitorowanie w przypadku zastosowania techniki bramkowania czy śledzenia ruchów guza.

Najnowszym osiągnięciem w IGRT jest integracja rezonansu magnetycznego z aparatem terapeutycznym. MRI (ang. Magnetic Resonance Imaging) to wszechstronna metoda obrazowania różnych kontrastów tkanek w 1D, 2D, 3D i 4D, niewymagająca użycia promieniowania jonizującego w celu obrazowania tkanek. Funkcjonalny MRI (fMRI) dodatkowo dostarcza również informacje funkcjonalne,daje możliwość wyznaczenia przekrojów w obrębie objętości guza i zdrowej tkanki, zapewniając tym samym podwójną korzyść. W obrębie objętości guza celem jest określenie, które części są bardziej wrażliwe na promieniowanie i mogą być leczone mniejszą dawką promieniowania jonizującego, a które potrzebować będą wyższej dawki. W przypadku zdrowych tkanek i narządów fMRI pozwala rozpoznać dobrze funkcjonujące fragmenty, co umożliwiadostosowanie planu leczenia, korekcję ewentualnych ruchów pacjenta, jak również uwzględnia potencjalne zmiany anatomiczne powstałe w wyniku leczenia. Obecnie integracja systemu obrazowania MR oraz aparatu terapeutycznego umożliwia łatwiejsze zlokalizowanie napromienianej objętości oraz sterowanie pozycją pacjenta $\mathrm{w}$ czasie rzeczywistym w trakcie napromieniania. Wyższe natężenia pola magnetycznego zapewniają lepszą jakość obrazu, potencjalnie stanowiącą podstawę przyszłej pracy związanej z teksturą 
obrazu, dostarczając $\mathrm{w}$ ten sposób znaczących informacji dla technik leczenia sterowanych ruchem i ostatecznie lepszej opieki nad pacjentem. Aktualne postępy w technologii obrazowania MR w radioterapii obiecują ulepszoną wizualizacje tkanek miękkich w czasie rzeczywistym, zmniejszenie marginesu leczenia dla wszystkich docelowych obszarów, optymalizacje wiązki, zmniejszenie toksyczności leczenia, zwiększenie dostarczanej dawki oraz dostęp do techniki VMAT (ang. Volumetric Arc Therapy). Rozwój obrazowania od 2D do 4D to przede wszystkim poprawa dokładności ułożenia pacjenta oraz większa precyzja dostarczania promieniowania. MRI to opcja, która może zapewnić wizualizację w czasie rzeczywistym dla prawdziwie adaptacyjnej radioterapii $[1,2,3]$.

\section{Wybór planu leczenia w codziennej praktyce}

W ciągu ostatniej dekady rozwój radioterapii nastąpił bardzo szybko. Dzięki zaawansowanym technikom leczenia(IMRT czy VMAT)możliwe jest precyzyjne dostarczenie dawki do docelowej objętości oraz zmniejszenie dawki w zdrowych tkankach [4].Szczególnym wyzwaniem jest napromienianie zmian w obrębie miednicy. Docelowe objętości takie jak szyjka macicy, prostata czy pęcherz moczowy są podatne na duże deformacje spowodowane przez codzienne, zmienne wypełnienie pęcherza i jelit. Zwykle trudno je skorygować samym ułożeniem pacjenta, odpowiednią dietą czy wybranymi protokołami leczenia. Tym samym zaplanowany obszar leczenia opiera się na dużych marginesach, a to znacznie ogranicza możliwość oszczędzenia narządów krytycznych (OAR - ang. Organs At Risk) nawet przy użyciu bardziej zaawansowanych technik leczenia [5].

Zespół z Academic Medical Center w Amsterdamie (Holadnia) przeprowadził badanie, którego celem było oszacowanie wykonalności strategii adaptacyjnej - wyboru planu leczenia opartego na CBCT - w przypadku radioterapii raka odbytnicy. Objętość docelowa jest podatna na duże odkształcenia, zatem strategia wyboru planu leczenia mogłaby zwiększyć precyzję dostarczania dawki promieniowania z korzyścią dla pacjenta. Do badania wybrano 11 pacjentów z rakiem odbytnicy leczonych strategią nieadaptacyjną, przewidując po pięć CBCT na pacjenta. Symulacja strategii wyboru planu leczenia obejmowała utworzenie trzech obszarów PTV (ang. Planning Target Volume) dla każdego pacjenta, w których zmieniono górny margines mezorektum. Po każdym CBCT dwudziestu obserwatorów wybrało najmniejsze PTV obejmujące objętość docelową. Po tych początkowych pomiarach ustalono „złoty standard”, następne pomiary powtórzono miesiąc później. W przypadku pierwszego pomiaru zgodność pomiędzy wyborem planu przez obserwatorów, a ustalonym „złotym standardem” wynosiła 69\%, w drugim pomiarze nastąpiła poprawa do 75\%. W przypadku drugiego pomiaru 10\% wyborów było mniejszych niż ustalony złoty standard. Wynik badania przestawił się następująco: przy selekcji planu pomiędzy obserwatorami na poziomie $75 \%$ możliwe jest wprowadzenie strategii wyboru planu leczenia dla pacjentów z rakiem odbytnicy [6].

Ten sam zespół z Academic Medical Centeropracował własną strategię opierająca się na doborze planu leczenia dostosowaną do zakresu możliwych zmian kształtu napromienianej objętości. Jest to strategia adaptacyjna, w której przed napromienianiem wykonuje się wiele planów leczenia. Każdy indywidualny plan zawiera mniejsze marginesy niż te tworzone standardowo. Jest to szczególnie skutecznepodejście w przypadku raka szyjki macicy i pęcherza moczowego, ponieważ możliwe odkształcenia docelowych objętości można w większości przewidzieć na podstawie wypełnienia pęcherza moczowego.W przypadku raka szyjki macicy i pęcherza moczowego wykonywane są skany CT (lub MR) na pełnym i pustym pęcherzu w celu stworzenia docelowych struktur objętościowych obejmujących zakres możliwych zmian kształtu.W przypadku raka odbytnicy należy skupić się na marginesach wokół deformującej się objętości docelowej. Opierając się na codziennym CBCT wybierany jest plan leczenia najlepiej pasujący w danym dniu terapii. Stosując taką strategię można znacznie zmniejszyć marginesy PTV, a tym samym ograniczyć dawkę w OAR i toksyczność leczenia.

Warto zastanowić się nad możliwością kreowania protokołów również dla innych obszarów napromieniania poza miednicą na przykład dla płuc czy przełyku. W tym obszarze przemieszczenie zmiany jest raczej nieprzewidywalne, tym samym codzienny wybór planu leczenia mógłby okazać się korzystnym rozwiązaniem.

Mimo wielu korzystnych aspektów, wybór planu leczenia w codziennej praktyce stawia wyzwania dla całego zespołu terapeutycznego. Początkowe skany CT z różnym wypełnieniem pęcherza pozostają tylko „migawkami” pewnego momentu i trudno by mogły reprezentować prawdziwe zmiany objętości podczas 
całego leczenia. Co więcej wybierając najlepszy plan konieczna jest znajomość docelowej objętości, opierająca się na obrazie i jakości CBCT [5]. Wymaga to odpowiedniego szkolenia osoby odpowiedzialnej za wybór konkretnego planu w danym dniu oraz wypracowaniekonkretnego protokołu klinicznego dla całej procedury.

Obecnie podstawą do wdrożenia wyboru codziennego planu leczenia dostosowanego do konkretnego pacjenta oraz jego prawidłowej realizacji jest stworzenie „złotego standardu” - pisemnego protokołu zawierającego wszystkie aspekty i zasady danej procedury. Konieczna jest ścisła współpraca lekarzy, fizyków oraz elektroradiologów odpowiedzialnych za przebieg radioterapii.Po pierwsze należy stworzyć więcej niż jeden plan leczenia dla konkretnego pacjenta. Po drugie należy zastanowić się, czy jakość dostępnego obrazowania CBCT jest wystarczająca (czy nie występują artefakty utrudniające jego ocenę). Po trzecie, należy ustalić, kto jest odpowiedzialny za wybór odpowiedniego planu leczenia w ramach procedury.

Ze względu na wyzwania związanie z przygotowaniem odpowiedniej strategii wybór planu leczenia w codziennej praktyce nie jest jeszcze często praktykowanym rozwiązaniem, a to, czy wynikająca z tego redukcja dawki w zdrowych tkankach spowoduje mniej skutków ubocznych jest wciąż tematem do dalszych badań. Nie zostało jeszcze udowodnione, że strategia ta jest lepsza od tych obecnie praktykowanych [4].

\section{Bibliografia}

[1] M. Rossi, IGRT from 2D to 4D, changing the verification paradigm. 37 ESTRO conference Barcelona 2018.

[2] IJ. Das, KP. McGee, N. Tyagi, H. Wang, Role and future of MRI in radiation oncology. Br J Radiol. 2019 Feb; 92(1094):20180505.

[3] https://www.itnonline.com/article/mri-guided-radiation-therapy-o , 18.05.2019r.

[4] http://www.eonsmagazine.eu/springsummer-2017/adaptive-strategy-radiation-therapy-pelvis-planselection, 21.02.2019r.

[5] R. De Jong, Image Guided Adaptive RT: Challenges,pitfalls and opportunities using plan selection in daily clinical practice. 37 ESTRO conference Barcelona 2018.

[6] R. De Jong, L. Lutkenhaus, N. Van Wieringen et al., Plan selection strategy for rectum cancer patients: An interobserver study to assess clinical feasibility. Radiother. Oncol. 2016 Aug;120(2);207-11. 